\title{
Methodological interference of biochar in the determination of extracellular enzyme activities in composting samples
}

\author{
K. Jindo ${ }^{1,3}$, K. Matsumoto ${ }^{2}$, C. García Izquierdo ${ }^{1}$, T. Sonoki ${ }^{2}$, and M. A. Sanchez-Monedero ${ }^{1}$ \\ ${ }^{1}$ Centro de Edafología y Biología Aplicada del Segura (CEBAS-CSIC), Department of Soil Conservation and Waste \\ Management. Campus Universitario de Espinardo, 30100 Murcia, Spain \\ ${ }^{2}$ Faculty of Agriculture and Life-Sciences, Hirosaki University, Bunkyo-cho, Hirosaki, Aomori 036-8561, Japan \\ ${ }^{3}$ Institute of Industrial Science, the University of Tokyo, 4-6-1 Komaba Meguro-Ku, Tokyo 153-8505, Japan \\ Correspondence to: K. Jindo (keijindo@ hotmail.com)
}

Received: 28 February 2014 - Published in Solid Earth Discuss.: 26 March 2014

Revised: 9 June 2014 - Accepted: 12 June 2014 - Published: 29 July 2014

\begin{abstract}
Biochar application has received increasing attention as a means to trap recalcitrant carbon and enhance soil fertility. Hydrolytic enzymatic assays, such as $\beta$-glucosidase and phosphatase activities, are used for the assessment of soil quality and composting process, which are based on use of $p$-nitrophenol (PNP) derivatives as substrate. However, sorption capacity of biochar can interfere with colorimetric determination of the hydrolysed PNP, either by the sorption of the substrate or the reaction product of hydrolysis into biochar surface. The aim of the present work is to study the biochar sorption capacity for PNP in biochar-blended composting mixtures in order to assess its impact on the estimation of the colorimetric-based enzymatic assays. A retention test was conducted by adding a solution of known amounts of PNP in universal buffer solution $(\mathrm{pH}=5,6.5$ and 11 , corresponding to the $\beta$-glucosidase, acid and alkaline phosphatase activity assays, respectively), in samples taken at the initial stage and after maturation stage from four different composting piles (two manure composting piles; PM: poultry manure, CM: cow manure and two other similar piles containing $10 \%$ of additional biochar $(\mathrm{PM}+\mathrm{B}, \mathrm{CM}+\mathrm{B}))$. The results show that biochar-blended composts $(\mathrm{PM}+\mathrm{B}, \mathrm{CM}+\mathrm{B})$ generally exhibited low enzymatic activities, compared to manure compost without biochar (PM, CM). In terms of the difference between the initial and maturation stage of composting process, the PNP retention in biochar was shown higher at maturation stage, caused most probably by an enlarged proportion of biochar inside compost mixture after the selective degradation of easily decomposable organic matter. TThe retention of PNP on biochar was influenced by $\mathrm{pH}$ dependency
\end{abstract}

of sorption capacity of biochar and/or PNP solubility, since PNP was more efficiently retained by biochar at low $\mathrm{pH}$ values (5 and 6.5) than at high $\mathrm{pH}$ values (11).

\section{Introduction}

Agricultural use of biochar has been receiving attention as an alternative strategy for mitigation of greenhouse gas (GHG) emission as well as improvement of soil properties. In addition, high sorption character of biochar, similarly to activated carbon, makes it possible to contribute to reduction of several hazards (heavy metals, pesticide, and hydrocarbon) in soil (Yang et al., 2009). Furthermore, the suitability of biochar has been reported as an additional component for enhancing the composting quality by reducing the nitrogen volatilization due to sorption on surface of biochar (Steiner et al., 2010), mitigating $\mathrm{CH}_{4}$ emission due to the higher aeration in composting pile (Sonoki et al., 2012) and improving compost quality such as an intense humification process and more recalcitrant character (Dias et al. 2010; Jindo et al., 2012). Lately, the application of biochar-blended compost to soil can promote a synergistic effect on enhancing plant nutrition content and water-holding capacity (Lieu et al.2012) as well as contributing the immobilization of organic pollutants and heavy metal (Beesley et al., 2010).

In terms of the decomposition of organic matter during composting, enzymatic activities such as $\beta$-glucosidase and phosphatase are a useful tool to reflect dynamics of biodegradation process and provide valuable information about the 
stability and maturity of the compost (Vuorinen 2000; Mondini et al., 2004). The measurement of enzymatic activities is utilized not only for the composting process but also as an indicator of soil quality since they are involved in the dynamics of soil nutrient cycle (Jordan et al., 1995). These hydrolytic enzymes are measured by colorimetric determination of $p$ nitrophenol (PNP) which is formed as the reaction product of hydrolysis of different nitrophenyl derivatives used as a substrate: nitrophenyl- $\beta$-d-glucopyranoside (PNG) for $\beta$ glucosidase activity, and $p$-nitrophenyl phosphatase (PNPP) for alkaline and acid phosphatase activities. By contrast, $p$ nitrophenol is a well-known toxic compound in industrial sector, and is treated by absorption on activated carbon (Tang et al., 2007; Ivančev-Tumbas al 2008). Furthermore, some biochar, produced at high temperature, has similar absorption character to activated carbon (Hale et al., 2013) and interferes with the extraction of soluble organic compounds, leading to underestimation of soil microbial activities (Chan et al., 2007). Even though several works on the relation between microbial measurements and biochar exposure have been reported (Durenkamp et al., 2010; Bailey et al., 2011; Luo et al., 2013), further research is required for understanding the biochar interaction from the chemical, physical and biochemical point of view. Thies and Rillig (2009) proposed the utilization of spiking assays with specific molecules as internal standard to overcome potential interferences in the estimation of the microbial parameters.

The aim in present work was to study the influence of biochar as a composting component on the retention of the PNP generated from three colorimetric-based enzymatic assays (alkaline and acid phosphatases and $\beta$-glucosidase). The retention of PNP was tested in two different composting mixtures (poultry manure (PM) and cow manure (CM)) and other two similar composting mixtures containing biochar as an additional component $(\mathrm{PM}+\mathrm{B}, \mathrm{CM}+\mathrm{B})$.

\section{Materials and methods}

\subsection{Biochar preparation}

The production of biochar, made from broad-leaved tree (Quercus serrata Murray), was carried out using a Japanese traditional kiln at atmospheric pressure and a temperature range of $400-600^{\circ} \mathrm{C}$ with a final temperature of $550^{\circ} \mathrm{C}$. To analyse the physical properties of biochar, we grounded and sieved the biochar to less than $0.5 \mathrm{~mm}$ in diameter. The elemental content was measured with an elemental analyzer (Thermo Finnigan EA1112, Thermo Fisher Scientific, Inc., MA, USA). The $\mathrm{pH}$ was measured with a compact $\mathrm{pH}$ meter B-212 (HORIBA Ltd., Kyoto, Japan). Microporosity was evaluated by the iodine $\left(\mathrm{I}_{2}\right)$ number method, and methylene blue (MB) adsorption capacity was measured, following the initial methodology used by Gaspard et al. (2007). Surface area was measured with a BELSORP18PLUS (BEL Japan,

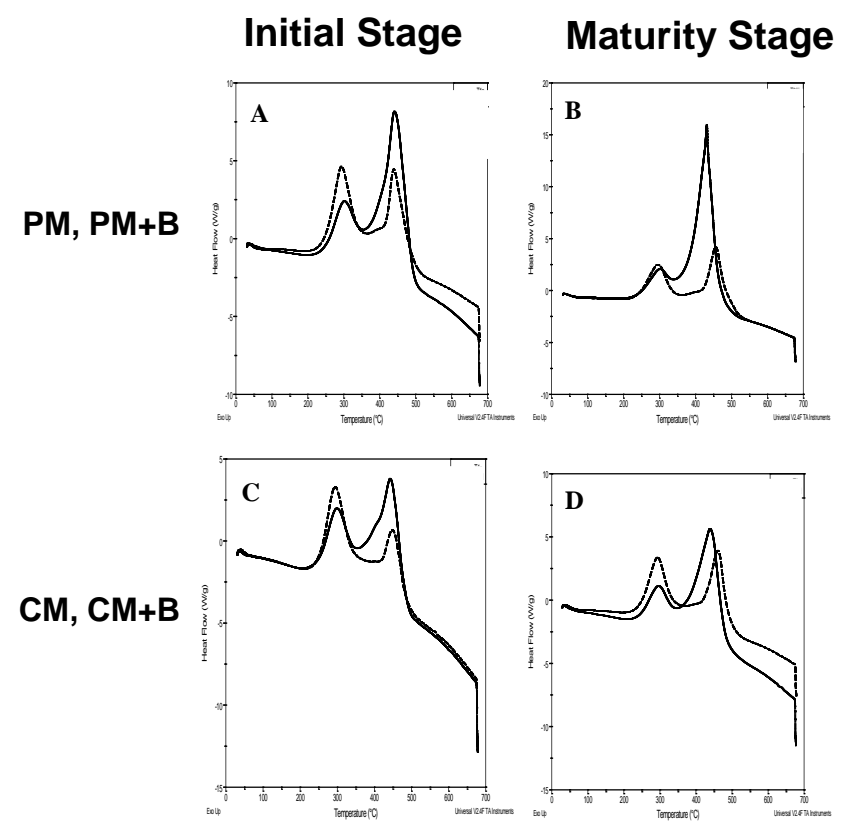

Figure 1. The TGS-DSC analysis of poultry manure PM, poultry manure + biochar $(\mathrm{PM}+\mathrm{B})$, cow manure $(\mathrm{CM})$, cow manure + biochar $(\mathrm{CM}+\mathrm{B})$. Dotted lines exhibit the compost without biochar, while continuous lines exhibit the compost with biochar. (A) initial stage of $\mathrm{PM}+\mathrm{B}$ and $\mathrm{PM}$; (B) maturity stage of $\mathrm{PM}+\mathrm{B}$ and $\mathrm{PM}$; (C) initial stage of $\mathrm{CM}+\mathrm{B}$ and $\mathrm{PM}$; (D) maturity stage of $\mathrm{CM}+\mathrm{B}$ and CM.

Inc., Osaka, Japan). The main characteristics of the obtained biochar are shown in Table 1.

\subsection{Raw materials and composting process}

Composting was carried out at Kanagi experimental farm of Hirosaki University. Two composting mixtures were prepared following initial proportion of organic waste: $\mathrm{CM}-$ cattle manure $(100.9 \mathrm{~kg})$ mixed with apple pomace $(76.8 \mathrm{~kg})$, rice straw $(9.7 \mathrm{~kg})$ and rice bran $(12.7 \mathrm{~kg}) ; \mathrm{PM}$ - poultry manure $(35.2 \mathrm{~kg})$ mixed with apple pomace $(141.8 \mathrm{~kg})$, rice straw $(9.9 \mathrm{~kg})$ and rice bran $(13.0 \mathrm{~kg})$. Another two composting mixtures $(\mathrm{CM}+\mathrm{B}$ and $\mathrm{PM}+\mathrm{B})$ were prepared by enriching the initial composting mixtures $\mathrm{CM}$ and $\mathrm{PM}$ with $20 \mathrm{~kg}$ of biochar. The organic waste mixtures were composted in cone shaped windrows with regular turnings and continuous monitoring of pile temperature and moisture. The principal physicochemical properties of the composting mixtures are described in Table 2, and further information on the composting process and characteristics of the composting mixtures can be found elsewhere (Sonoki et al., 2012). The composting process lasted approximately 3 months for all piles. A representative sample of each organic material was taken at the initial stage (I) and after maturation stage (M). These samples were collected from different spots of piles, mixed together, air dried and ground to $0.5 \mathrm{~mm}$. 
Table 1. Chemical and physical property of hardwood biochar (from broad-leaved tree (Quercus serrata Murray)).

\begin{tabular}{ccccccclcc}
\hline $\mathrm{C}$ & $\mathrm{O}$ & $\mathrm{H}$ & $\mathrm{N}$ & $\mathrm{P}$ & $\mathrm{K}$ & $\mathrm{pH}$ & $\begin{array}{l}\mathrm{MB} \\
\text { absorption } \\
\text { capacity }\end{array}$ & $\begin{array}{l}\text { Iodine } \\
\text { number }\end{array}$ & $\begin{array}{l}\text { Surface } \\
\text { area }\end{array}$ \\
\hline $\mathrm{g} \mathrm{kg}^{-1}$ & & & & & & - & $\mathrm{mg} \mathrm{kg}^{-1}$ & $\mathrm{mg} \mathrm{kg}^{-1}$ & $\mathrm{~m}^{2} \mathrm{~g}^{-1}$ \\
791.5 & 91.5 & 18.9. & 37.6 & 2.3 & 14.1 & 7.2 & 8.3 & 100 & 255.0 \\
\hline
\end{tabular}

\subsection{Thermogravimetric analysis (TGA)}

Thermal analysis of the organic material was measured using a SDT-2960 simultaneous DSC-TGA thermal analyzer (TA instruments) under static air atmosphere as follows: a temperature equilibrating at $30^{\circ} \mathrm{C}$ followed by a linear heating rate of $5^{\circ} \mathrm{C} \mathrm{min}^{-1}$ from 30 to $105^{\circ} \mathrm{C}$, an isotherm for $10 \mathrm{~min}$ and then continued ramping of $5^{\circ} \mathrm{C} \mathrm{min}{ }^{-1}$ from 105 to $680^{\circ} \mathrm{C}$. An index of thermal lability of the organic matter $\left(W_{2} / W_{1}\right)$, shown in Table 2, was calculated from the ratio of mass loss at $350-550{ }^{\circ} \mathrm{C}\left(W_{2}\right) /$ mass loss at $110-350{ }^{\circ} \mathrm{C}$ $\left(W_{1}\right)$ (Plante et al., 2009).

\subsection{Enzymatic analysis}

Alkaline and acid phosphatase and $\beta$-glucosidase activities were determined following the methods reported by Tabatabai and Bremmer (1971) and Eivazi and Tabatabai (1988), respectively, using $0.5 \mathrm{~g}$ of organic material, and $2 \mathrm{~mL}$ of modified universal buffer (MUB) containing the following substrate: alkaline phosphatase activity assay was performed at $\mathrm{pH} 11$ using $p$-nitrophenyl phosphatase (PNPP) as substrate. Meanwhile, acid phosphatase activity assay was performed with the same substrate at $\mathrm{pH} 5.5 ; \beta$-glucosidase activity was assayed at $\mathrm{pH} 6$ using $p$-nitrophenyl $\beta$-Dglucopiranoside (PNG) as substrate. In the three cases, the suspensions were incubated at $37^{\circ} \mathrm{C}$ for $1 \mathrm{~h}$. Enzymatic reactions were stopped by cooling in ice for $15 \mathrm{~min}$. Then, $0.5 \mathrm{~mL}$ of $\mathrm{CaCl}_{2} 0.5 \mathrm{M}$ and $2 \mathrm{~mL}$ of $\mathrm{NaOH} 0.5 \mathrm{M}$ (for phosphatases) or $2 \mathrm{~mL}$ of Tris (hydroxymethyl) aminomethane-sodium hydroxide (THAM-NaOH) $0.1 \mathrm{M} \mathrm{pH} 12$ (for $\beta$-glucosidase) were added .After the centrifugation and filtration, the $p$ nitrophenol (PNP), formed as product reaction from the three enzymatic assays, was determined at $398 \mathrm{~nm}$ using a spectrophotometer.

\subsection{PNP retention assay during the enzymatic activity analysis}

To study the retention of PNP during the analysis of the different enzymatic activities, the following spiking assay was performed: instead of adding the substrates (PNG and PNPP) at the beginning of the procedure, reaction product (PNP) was added with different concentration $(0,50,100$ and $\left.150 \mathrm{mg} \mathrm{L}^{-1}\right)$ to buffer solution $(\mathrm{pH}=5,6,5$ and 11 , corre-

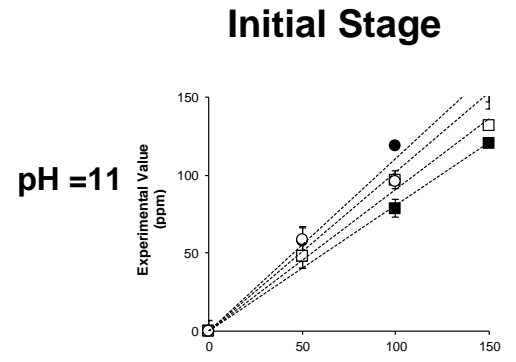

Maturity Stage
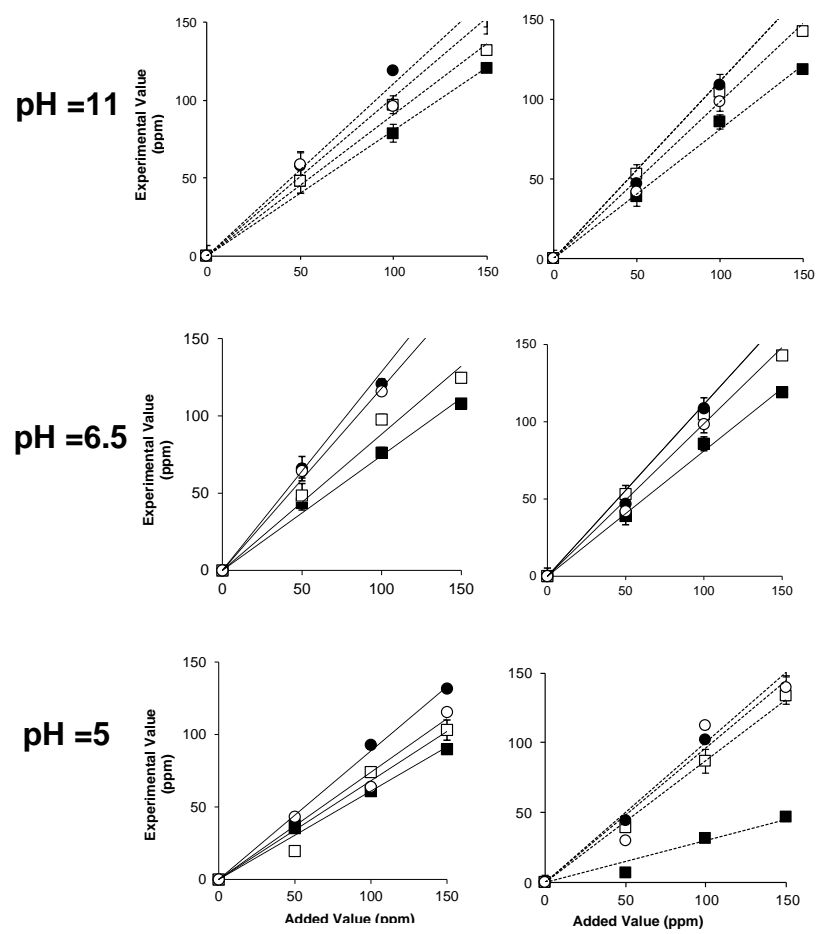

Figure 2. Retention of PNP with different $\mathrm{pH}$ solution in the compost samples of poultry manure PM $(\square)$, poultry manure + biochar $\mathrm{PM}+\mathrm{B}(\boldsymbol{\square})$, poultry manure control PM-C $(\bigcirc)$, and poultry manure + biochar control PMB-C $(\bullet)$ during the composting process.

sponding to the $\beta$-glucosidase, acid and alkaline phosphatase activity assays, respectively). After the incubation, the same procedure as for enzymatic assay, described in the previous section took place for PNP determination. This procedure allows evaluating the retention of PNP by the biochar during the analysis. Controls were performed similarly by adding the same amounts of PNP after the incubation period and before the measurement of the absorbance in the calibrated spectrophotometer (with an external PNP standard solution). These results are shown in Fig. 2. (CM and $\mathrm{CM}+\mathrm{B}$ ) and Fig. 3. (PM and PM+ B). Lately, the PNP retention was calculated by fitting the amount of PNP measured after the enzymatic determination $\left(\mathrm{PNP}_{\exp }\right)$ and the amount 
Table 2. Physical and chemical properties in poultry manure compost (PM), poultry manure blended with biochar (PM $+\mathrm{B})$, cow manure $(\mathrm{CM})$, and compost blended with biochar $(\mathrm{CM}+\mathrm{B})$.

\begin{tabular}{|c|c|c|c|c|c|c|c|c|c|c|}
\hline \multirow[t]{2}{*}{ Origin } & \multicolumn{5}{|c|}{ Initial stage } & \multicolumn{5}{|c|}{ Maturity stage } \\
\hline & $\begin{array}{c}\mathrm{C} \\
(\%)\end{array}$ & $\begin{array}{c}\mathrm{N} \\
(\%)\end{array}$ & $\begin{array}{c}\text { O.M. }{ }^{1} \\
(\%)\end{array}$ & $\mathrm{pH}$ & $W_{2} / W_{1}^{2}$ & $\begin{array}{c}\mathrm{C} \\
(\%)\end{array}$ & $\begin{array}{c}\mathrm{N} \\
(\%)\end{array}$ & $\begin{array}{c}\text { O.M. } \\
(\%)\end{array}$ & $\mathrm{pH}$ & $W_{2} / W_{1}$ \\
\hline PM & 36.9 & 1.7 & 79.9 & 5.8 & 0.5 & 27.9 & 2.9 & 55.2 & 8.2 & 0.8 \\
\hline $\mathrm{PM}+\mathrm{B}$ & 39.9 & 1.7 & 84.9 & 5.8 & 1.0 & 33.6 & 2.0 & 73.0 & 7.8 & 2.3 \\
\hline $\mathrm{CM}$ & 35.6 & 1.7 & 75.9 & 6.6 & 0.4 & 29.8 & 2.4 & 59.7 & 7.7 & 0.8 \\
\hline $\mathrm{CM}+\mathrm{B}$ & 37.1 & 1.3 & 79.7 & 7.0 & 0.9 & 31.5 & 1.8 & 68.8 & 7.6 & 1.6 \\
\hline
\end{tabular}

Initial Stage Maturity Stage
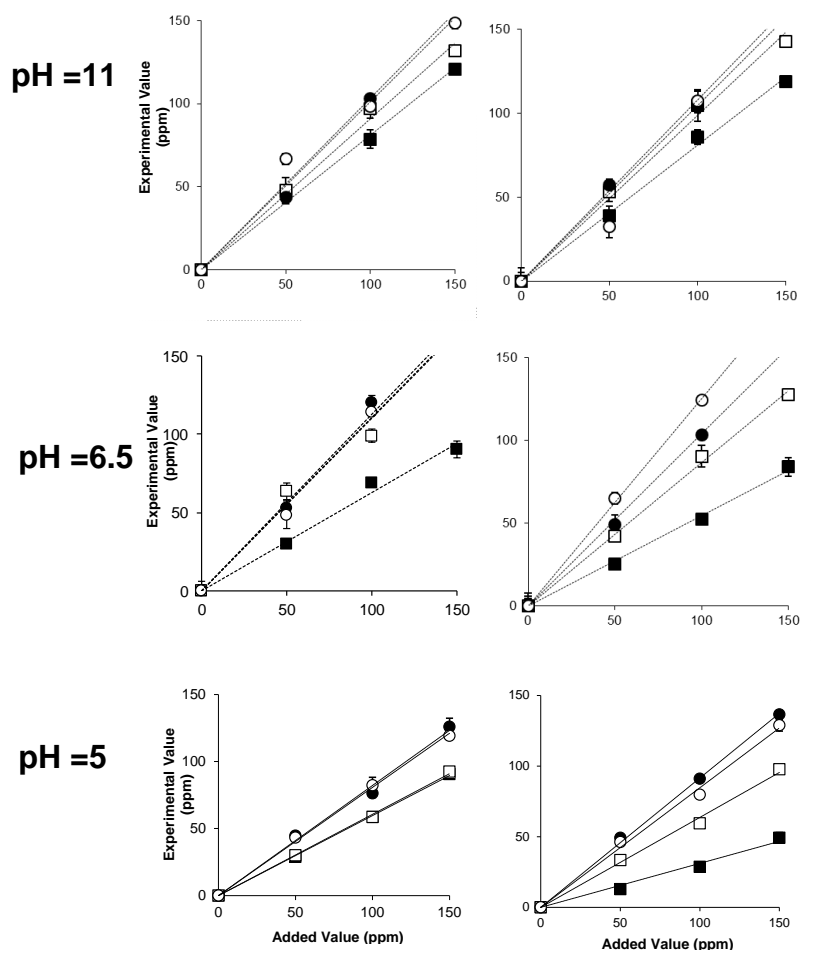

Figure 3. Retention of PNP with different $\mathrm{pH}$ solution in the compost samples of cow manure $\mathrm{CM}(\square)$, cow manure + biochar $\mathrm{CM}+\mathrm{B}(\boldsymbol{\square})$, cow manure control CM-C (o), and cow manure + biochar control CMB-C $(\bullet)$ during the composting process.

of PNP added in the control ( $\left.\mathrm{PNP}_{\mathrm{add}}\right)$ to a linear equation $\left(\mathrm{PNP}_{\exp }=k \times \mathrm{PNP}_{\mathrm{add}}\right)$, where $k$ was the slope of the linear fitting. The percentage of PNP recovered in the enzymatic determination was calculated as $100 \cdot k$, whereas the percentage of PNP retention was calculated as $100 \cdot(1-k)$. PNP retention assays were performed in duplicate for all treatments and are shown in Table 3.

\section{Results and discussion}

\subsection{Characteristics of the composting mixtures}

Different composting mixtures were selected at different stages of the composting process to cover the range of organic matter stabilization degree. The different nature of the organic matter at different stages of the biodegradable process and the property of the recalcitrant biochar was assessed by thermogravimetry (Lyons et al., 2006; Tsui and Juan, 2010; Manya et al., 2013). Basically, the TGS-DSC diagrams are characterized by two main mass losses, showing two exothermic peaks, and these correspond respectively to the volatilization of light compounds such as aliphatic molecules or carbohydrates and another to the oxidation of high molecular weight components (Fig. 1.). Comparing the graph shapes between the samples from initial stage (Fig. 1a and c) and from maturity stage (Fig. $1 \mathrm{~b}$ and d), the second wave of peak, generated by mass loss at $350-550{ }^{\circ} \mathrm{C}$, was pronouncedly shown at maturity stage, due to the selective degradation of labile organic materials during the composting process. As a consequence, the index of lability of $W_{2} / W_{1}$ in all samples at the maturity stage is higher than those at the initial stage (Table 2).

The influence of adding biochar into the composting mixture at the initial phase (Fig. 1a and c) is observed by the higher peak of second wave in biochar-blended composts $(\mathrm{PM}+\mathrm{B}, \mathrm{CM}+\mathrm{B})$, which are described in dotted lines (Fig. 1a and c). This is because biochar that has resulted from biochar originated from hardwood mostly consists of recalcitrant compounds, which are combusted at $W_{2}$ range $\left(350-550{ }^{\circ} \mathrm{C}\right)$ in an oxidant atmosphere of air. Consequently, $W_{2} / W_{1}$ ratio at initial time (Table 2) increased in biocharblended piles $(\mathrm{PM}+\mathrm{B}, \mathrm{CM}+\mathrm{B})$ from the piles of nonbiochar addition (PM, CM). After maturation stage (Table 2), $W_{2} / W_{1}$ ratio markedly increased in the biochar-blended composts $(\mathrm{PM}+\mathrm{B}, \mathrm{CM}+\mathrm{B}, 2.3$, and 1.6, respectively), reflecting the high relative proportion of recalcitrant biochar. 
Table 3. Percentage of PNP recovery calculated by the linear fitting of the measured amount of PNP (PNP exp) and the amount of PNP added $\left(\mathrm{PNP}_{\mathrm{add}}\right)$, according to the equation $\mathrm{PNP}_{\mathrm{exp}}=k \times \mathrm{PNP}_{\mathrm{add}}$. The percentage of PNP recovery is expressed as $100 \cdot k$. Poultry manure compost $(\mathrm{PM})$, poultry manure blended with biochar $(\mathrm{PM}+\mathrm{B})$, cow manure $(\mathrm{CM})$, and cow manure blended with biochar $(\mathrm{CM}+\mathrm{B})$.

\begin{tabular}{|c|c|c|c|c|c|c|c|c|}
\hline \multirow[t]{3}{*}{ Enzymatic assay } & \multicolumn{4}{|c|}{ Poultry manure } & \multicolumn{4}{|c|}{ Cow manure } \\
\hline & \multicolumn{2}{|c|}{ Initial stage } & \multicolumn{2}{|c|}{ Maturity stage } & \multicolumn{2}{|c|}{ Initial phase } & \multicolumn{2}{|c|}{ Maturity stage } \\
\hline & $\mathrm{PM}$ & $\mathrm{PM}+\mathrm{B}$ & $\mathrm{PM}$ & $\mathrm{PM}+\mathrm{B}$ & $\mathrm{CM}$ & $\mathrm{CM}+\mathrm{B}$ & $\mathrm{CM}$ & $\mathrm{CM}+\mathrm{B}$ \\
\hline $\begin{array}{l}\text { Alkaline Phos- } \\
\text { phatase (pH 11) }\end{array}$ & $\begin{array}{c}88.9 \\
(3.9)^{\mathrm{a}}\end{array}$ & $\begin{array}{l}78.6 \\
(5.2)\end{array}$ & $\begin{array}{c}96.03 \\
(3.4)\end{array}$ & $\begin{array}{l}80.8 \\
(2.9)\end{array}$ & $\begin{array}{l}91.3 \\
(3.4)\end{array}$ & $\begin{array}{l}84.8 \\
(3.4)\end{array}$ & $\begin{array}{l}90.2 \\
(3.5)\end{array}$ & $\begin{array}{l}70.5 \\
(4.6)\end{array}$ \\
\hline $\begin{array}{l}\text { Acid Phos- } \\
\text { phatase (pH 6.5) }\end{array}$ & $\begin{array}{l}84.6 \\
(4.9)\end{array}$ & $\begin{array}{l}71.3 \\
(2.8)\end{array}$ & $\begin{array}{l}80.8 \\
(5.1)\end{array}$ & $\begin{array}{l}43.5 \\
(0.7)\end{array}$ & $\begin{array}{l}112.9 \\
(6.5)\end{array}$ & $\begin{array}{l}62.2 \\
(3.5)\end{array}$ & $\begin{array}{l}86.3 \\
(2.9)\end{array}$ & $\begin{array}{l}55.9 \\
(1.8)\end{array}$ \\
\hline $\begin{array}{l}\beta \text {-gluco- } \\
\text { sidase (pH 5) }\end{array}$ & $\begin{array}{l}72.7 \\
(5.6)\end{array}$ & $\begin{array}{l}59.0 \\
(1.9)\end{array}$ & $\begin{array}{l}89.8 \\
(3.5)\end{array}$ & $\begin{array}{l}39.2 \\
(2.9)\end{array}$ & $\begin{array}{l}61.2 \\
(1.3)\end{array}$ & $\begin{array}{l}60.3 \\
(1.0)\end{array}$ & $\begin{array}{l}63.8 \\
(2.1)\end{array}$ & $\begin{array}{l}32.7 \\
(1.9)\end{array}$ \\
\hline
\end{tabular}

a Standard error in parentheses.

\subsection{Study of the PNP retention on biochar-blended compost}

The colorimetric determination of PNP was influenced by the degree of stability of the composting mixtures, which affected the relative proportion of biochar in the mixture. The biochar-blended composts showed more retention of PNP, especially in the case of maturity stage (Figs. 2 and 3). The amount of PNP retained by the biochar-blended composting mixtures $(\mathrm{CM}+\mathrm{B}$ and $\mathrm{PM}+\mathrm{B})$ varied from $41 \%$ in the starting composting mixtures up to $74 \%$ in mature composts. This result might have been attributed to gained dominance of biochar amount inside composting mixtures which was gradually increased during the composting process. The recalcitrance of biochar character was retained until the maturation stage, while labile organic materials in the composting piles were lost due to the selective degradation, as already shown by TGS measurement (Fig. 1). Therefore the effect of the physico-chemical properties of biochar on the compost structure is expected to be more dominant in the mature stage than at the initial stage.

The PNP retention by biochar also depends on $\mathrm{pH}$ status of the buffer solution, used by each specific enzymatic activity. At high $\mathrm{pH}$ condition $(\mathrm{pH} 11)$, representing alkaline phosphatase essay, the PNP retention is observed in the range between 15 and $30 \%$ of the added PNP (Table 3). However, the same spiking assays performed at low $\mathrm{pH}(\mathrm{pH} 6.5$ and 5 from acid phosphatase and $\beta$-glucosidase activities, respectively) exhibited high PNP retention from $30 \%$ (acid phosphatase determination in $\mathrm{PM}+\mathrm{B}$ ) up to $70 \%$ which is the case of the $\beta$-glucosidase determination in $\mathrm{CM}+\mathrm{B}$. These results are in agreement with the $\mathrm{pH}$ dependence of phenol adsorption efficiency by activated carbon reported by several authors (Ayranci and Duman 2005; Tang et al., 2007), concluding that the absorption efficiency of activated carbon is lower in alkaline solution than neutral or acid solution. An increase in the amount of $\mathrm{OH}$ ions in alkaline solution reduces the diffusion of phenol ions due to an electrostatic re- pulsion of negatively charged site of the sorbent and phenolic ions. As the $\mathrm{pH}$ increases, the surface charge of pyrogenic materials became negative and decreases its sorption capacity (Beker et al., 2010). Furthermore, other authors (Zhang et al., 2010) reported that, regarding the mobility of biochar particles, the lower the $\mathrm{pH}$ solution, the lesser transport of the biochar particles.

The sorption affinity of pyrogenic material is also influenced by physical properties such as microporosity and surface area, as well as chemical properties such as hydrophobicity in relation with $\mathrm{O} / \mathrm{C}$ content (Al-Asheh et al., 2004; Ko et al., 2007; Tsui and Juang, 2010). Micropore and mesopore structure, estimated respectively by the iodine number and the methylene blue adsorption, are usually enlarged at high pyrolysis temperature together with surface area. Overall, all these biochar properties are dominantly defined by feedstock and pyrolysis conditions used for the preparation of the biochar (Uchimiya et al., 2010).

The PNP retention by the organic matter of the composting mixtures prepared without biochar (PM and $\mathrm{CM}$ ) was also affected by the $\mathrm{pH}$ gradient. Table 3 shows that, at low $\mathrm{pH}$ solution (pH 5, initial stage of composting), $\mathrm{CM}$ has $69 \%$ of PNP recovery, meaning $31 \%$ of PNP was retained. This methodological problem in the determination of the enzymatic activities is well-known in clay mineral soils or soils enriched with organic matter (Tabatabai and Bremer 1971; Trasar-Cepeda et al 1988). Organic material containing a large amount of humic substances is known to easily absorb PNP molecules (Chen et al., 2009). In order to tackle this obstacle, several authors have recently recommended testing the soil enzymatic assays in samples blended with biochar to ensure the assumption of saturating substrate concentrations, and if necessary amending the protocols before initiating the assays (Swine et al., 2013). In practice, and in order to overcome the underestimation by absorption on biochar, PazFerreiro et al. $(2012,2014)$ used different calibration curves for each different type of amendment to acquire an accurate 
measure of soil enzymatic activities. This problem is even more complex in composting samples, where the degradation of labile organic matter causes a progressive enrichment in the proportion of biochar in the mixture. The different proportion of biochar in the starting mixtures and the mature compost also requires the adaptation and optimization of the enzymatic assay to the different composting stage.

In conclusion, the presence of biochar limited the validity of enzymatic essays for the colorimetric determination of PNP since PNP was strongly retained in biochar-blended compost. It is a challenge to improve the colorimetric methods of PNP determination for biochar interaction, and a clearcut solution has not been found yet. Further research is necessary in order to measure with colorimetric methods potential enzymatic activity in the presence of biochar.

Acknowledgements. We are very grateful for financial support by the Japan Society of the Promotion of science as well as CSIC programmes of bilateral project. This research was financed by a grant from the Spanish Ministry of Science and Innovation, research project AGL2012-40143-C02-01. We would like to express our deep gratitude to Mr. Sasaki for making possible the pyrolysis process and for his inspiration to perform this research.

Edited by: J. Paz-Ferreiro

\section{References}

Al-Asheh, S., Banat, F., and Masad, A.: Kinetics and equilibrium sorption, studies of 4-nitrophenol on pyrolyzed and activated oil shale residue, Environ. Geol., 45, 1109-1117, 2004.

Ayranci, E. and Duman, O.: Adsorption behaviours of some phenolic compounds onto high specific area activated carbon cloth, J. Hazard. Mater., 124, 125-132, 2005.

Bailey, V. L., Fansler, S. J., Smith, J. L., and Bolton, H.: Reconciling apparent variability in effects of biochar amendment on soil enzyme activities by assay optimization, Soil Biol. Biochem., 43, 296-301, 2010.

Beesley, L., Moreno-Jiménez, E., and Gomez-Eyles, J. L.: Effects of biochar and greenwaste compost amendments on mobility, bioavailability and toxicity of inorganic and organic contaminants in a multi-element polluted soil, Environ. Pollut., 158, 2282-2287, 2010.

Beker, U., Ganbold, B., Dertli, H., and Gülbayir, D. D.: Adsorption of phenol by activated carbon: influence of activation methods and solution pH, Energ. Convers. Manage., 51, 235-240, 2010.

Chan, K. Y., Van Zwieten, L., Meszaros, I., Downie, A., and Joseph, S.: Agronomic values of green waste biochar as a soil amendment, Aust. J. Soil Res., 45, 629-634, 2007.

Chen, H., Berndtssonm R., Mingguangm M., and Zhu, K.: Characterization of insolubilized humic acid and its sorption behaviors, Environ. Geol., 57, 1847-1853, 2009.

Dias, B. O., Silva, C. A., Higashikawa, F. S., Roig, A., and SánchezMonedero, M. A.: Use of biochar as bulking agent for the composting of poultry manure: effect on organic matter degradation and humification, Bioresource Technol., 101, 1239-1246, 2010.
Durenkamp, M., Luo, Y., and Brookes, P. C.: Impact of black carbon addition to soil on the determination of soil microbial biomass by fumigation extraction, Soil Biol. Biochem., 42, 2026-2029, 2010.

Eivazi, F. and Tabatabai, M. A.: Glucosidases and galactosidases in soils, Soil Biol. Biochem., 20, 601-606, 1988.

Gaspard, S., Altenor, S., Dawson, E. A., and Barnes, P. A., and Ouensanga A.: Activated carbon from vetiver roots: gas and liquid adsorption studies, 2007, J. Hazardous. Mater., 144, 73-81, 2007.

Hale, S. H., Jensen, J., Jakob, L., Oleszczuk,, P., Hartnik, T., Henriksen, T., Okkenhaug, G., Martinsen, V., and Cornelissen, G.: Short-Term Effect of the Soil Amendments Activated Carbon, Biochar, and Ferric Oxyhydroxide on Bacteria and Invertebrates, Environ. Sci. Technol., 47, 8674-8683, 2013.

Ivančev-Tumbas, I., Hobby, R., Küchle, B., Panglisch, S., and Gimbel, R.: p-Nitrophenol removal by combination of powdered activated carbon adsorption and ultrafiltration - comparison of different operational modes, Water Res., 42, 4117-4124, 2008.

Jindo, K., Suto, K., Matsumoto, K., García, C., Sonoki, T., and Sanchez-Monedero, M. A.: Chemical and biochemical characterisation of biochar-blended composts prepared from poultry manure, Bioresource Technol., 110, 396-404, 2012.

Jordan, D., Kremer, R. J., Bergfield, W. A., Kim, K. Y., and Cacnio, V. N.: Evaluation of microbial methods as potential indicators of soil quality in historical agricultural fields, Biol Fert. Soils., 19, 297-302, 1995.

Ko, C. H., Fan, C., Chiang, P. N., Wang, M. K., and Lin, K. C.: $p$-Nitrophenol, phenol and aniline sorption by organo-clays, J. Hazard. Mater., 149, 275-282, 2007. .

Liu, J., Schulz, H., Brandl, S., Miehtke, H., Huwe, B., and Glaser, B.: Short-term effect of biochar and compost on soil fertility and water status of a Dystric Cambisol in NE Germany under field conditions, J. Plant Nutr. Soil Sc., 1-10, 2012.

Lyons, G. A., Sharma, H. S. S., Kilpatrick, M., Cheung, L., and Moore, S.: Monitoring of changes in substrate characteristics during mushroom compost production, J. Agr. Food Chem., 54, 4558-4667, 2006.

Luo, Y., Durenkamp, M., De Nobili, M., Lin, Q., Devonshire, B. J., and Brookes, P. C.: Microbial biomass growth, following incorporation of biochars produced at $350^{\circ} \mathrm{C}$ or $700^{\circ} \mathrm{C}$, in a silty-clay loam soil of high and low pH, Soil Biol. Biochem., 57, 513-523, 2013.

Manyà, J. J., Roca, F. X., and Perales, J. F.: TGA study examining the effect of pressure and peak temperature on biochar yield during pyrolysis of two-phase olive mill waste, J. Anal. Appl. Pyrol., 103, 86-98, 2012.

Mondini, C., Fornasier, F., and Sinicco, T.: Enzymatic activity as a parameter for the characterization of the composting process, Soil Biol. Biochem., 36, 1587-1594, 2004.

Paz-Ferreiro, J., Gascó, G., Gutiérrez, B., and Méndez, A.: Soil biochemical activities and the geometric mean of enzyme activities after application of sewage sludge and sewage sludge biochar to soil, Biol. Fert. Soils., 48, 511-517, 2012.

Paz-Ferreiro, J., Fu, S., Méndez, A., and Gascó, G.: Interactive effect of biochar and the earthworm Pontoscolex corethrurus on plant productivity and soil enzyme activity, J. Soils Sediments, 14, 483-494, 2014. 
Plante, A. F., Fernandez, J. M., and Leifeld. J.: Application of thermal analysis techniques in soil science, Geoderma, 153, 1-10, 2009.

Sonoki, T., Furukawa, T., Jindo, K., Suto, K., Aoyama, M., and Sanchez-Monedero, M. A.: Influence of biochar addition on methane metabolism during thermophilic phase of composting, J. Basic Microb., 52, 1-5, 2012.

Steiner, C., Glaser, B., Teixeira, W. G., Lehmann, J., Blum, W. E. H., and Zech, W.: Nitrogen retention and plant uptake on a highly weathered central Amazonian Ferralsol amended with compost and charcoal, J. Plant Nutr. Soil Sc., 171, 893-899, 2009.

Swine, M., Obrike, R., Clark, J. M., and Shaw, L. J.: Biochar Alteration of the Sorption of Substrates and Products in Soil Enzyme Assays, Appl. Environ. Soil Sci., 1-5, 2013.

Tabatabai, M. A. and Bremner, J. M.: Michaelis constants of soil enzymes, Soil Biol. Biochem., 3, 317-323, 1971.

Tang, D., Zheng, Z., Lin, K., Luan, J., and Zhang, J.: Adsorption of $p$-nitrophenol from aqueous solutions onto activated carbon fiber, J. Hazard. Mater., 143, 49-56, 2007.

Thies, J. E. and Rillig, M. C.: Characteristics of biochar: biological properties, in: Biochar for Environmental Management: Science and Technology, edited by Lehmann, J. and Joseph, S., London, 85-105, 2009.
Trasar-Cepeda, M. C. and Sotres, G. F.: Kinetics of acid phosphatase activity in various soils of Galicia, Soil Biol. Biochem. 20, 275-280, 1998.

Tsui, L. and Juang, M. A.: Effects of composing on sorption capacity of bagasse-based chars, Waste Manage., 30, 995-999, 2010.

Uchimiya, M., Lima, I. M., Klasson, K. T., and Wartelle, L. H. Contaminant immobilization and nutrient release by biochar soil amendment: roles of natural organic matter, Chemosphere, 80 , 935-940, 2010.

Vuorinen, A. H.: Effect of the bulking agent on acid and alkaline phosphomonoesterase and $\beta$-D-glucosidase activities during manure composting, Bioresource Technol., 75, 133-138, 2000.

Yang, X. B., Ying, G. G., Peng, P. A., Wang, L., Zhao, J. L., Zhang, L. J., Yuan, P., and He, H. P.: Influence of biochars on plant uptake and dissipation of two pesticides in an agricultural soil, J. Agr. Food Chem., 58, 7915-7921, 2010.

Yu, J. T., Dehkhoda, A. M., and Ellis, N.: Development of biocharbased catalyst for transesterification of Canola oil, Energ. Fuel., 25, 337-344, 2011.

Zhang, W., Niu, J., Morales, V. L., Chen, X., Hay, A. G., Lehmann, J., and Steenhuis, T. S.: Transport and retention of biochar particles in porous media: effect of $\mathrm{pH}$, ionic strength, and particle size, Ecohydrology, 3, 497-508, 2010. 